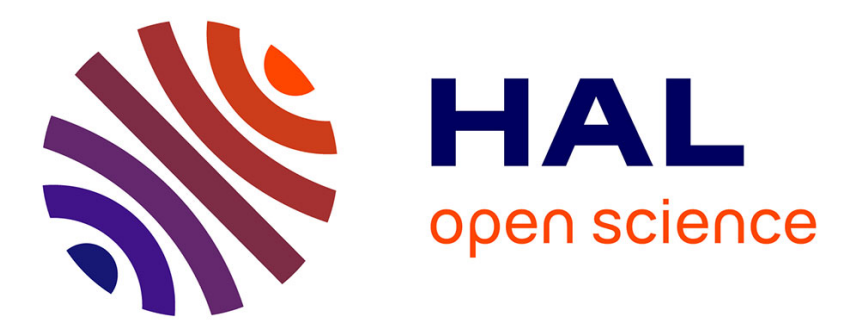

\title{
Méthode d'accès rapide aux dépassements de capacité dans les petits calculateurs utilisés comme analyseurs multicanaux: l'adressage indirect programme
}

R. Chaminade, J. Pain, M. Lechaczynski, J.C. Faivre, J. Demeuzois, J. Durruty

\section{To cite this version:}

R. Chaminade, J. Pain, M. Lechaczynski, J.C. Faivre, J. Demeuzois, et al.. Méthode d'accès rapide aux dépassements de capacité dans les petits calculateurs utilisés comme analyseurs multicanaux: l'adressage indirect programme. Revue de Physique Appliquée, 1969, 4 (2), pp.134-134. 10.1051/rphysap:0196900402013401 . jpa-00243180

\section{HAL Id: jpa-00243180 https://hal.science/jpa-00243180}

Submitted on 1 Jan 1969

HAL is a multi-disciplinary open access archive for the deposit and dissemination of scientific research documents, whether they are published or not. The documents may come from teaching and research institutions in France or abroad, or from public or private research centers.
L'archive ouverte pluridisciplinaire HAL, est destinée au dépôt et à la diffusion de documents scientifiques de niveau recherche, publiés ou non, émanant des établissements d'enseignement et de recherche français ou étrangers, des laboratoires publics ou privés. 


\title{
MÉTHODE D'AGGÈS RAPIDE AUX DÉPASSEMENTS DE GAPAGITÉ DANS LES PETITS GALGULATEURS UTILISÉS GOMME ANALYSEURS MULTIGANAUX : L'ADRESSAGE INDIREGT PROGRAMME
}

\author{
R. GHAMINADE, J. PAIN, M. LEGHACZYNSKI, J. G. FAIVRE, \\ J. DEMEUZOIS et J. DURRUTY, \\ Service de Physique Nucléaire à Moyenne Énergie, G.E.N., Saclay.
}

\begin{abstract}
Résumé. - Pour un calculateur ayant une mémoire de 12 bits par exemple, la capacité d'une adresse est limitée à 4095 événements. Pour accroître la capacité des canaux en dépassement, on utilise généralement une table associative des dépassements. Mais la recherche d'un canal particulier, dans cette table, pour visualisation ou mise à jour, est un processus lent. Pour y remédier, nous utilisons l'adressage indirect programmé pour l'accès à un canal particulier dans la table double précision remplaçant la table associative. Nous limitons la capacité des canaux à 2047, soit 11 bits, pour réserver le douzième bit, bit supérieur, comme bit d'adressage indirect. Quand le douzième bit est à 0 , le comptage du canal est représenté par les 11 premiers bits. Si le comptage dépasse 2047 événements, le douzième bit est imposé en permanence à 1 , les 11 premiers bits représentent alors l'adresse (ou l'index d'accès) dans la table en double précision où se trouve maintenant le comptage. Le calculateur PDP 8 comporte une instruction de test du douzième bit.
\end{abstract}

Abstract. - In a small digital computer having, for example, 12 bits memory, the storage capacity is limited to 4095 events. To increase the capacity for channels with overpasses, one ordinarily uses an associative overflow table, but the search in this table of a particular channel, for display or up-dating purposes, is slow. To cure that we use software indirect addressing to access a particular channel in the double precision overpass table which replaces the associative overflow table. We limit the channel capacity to 2047 , or 11 bits, to keep the 12 th upper bit as an indirect address bit. If the 12 th bit is 0 , the channel content is the channel count as normally. But if the count overpasses 2047 the 12 th bit is set and maintained to 1 , the count is then replaced, in the channel, by the address (or the index) in the double precision table where one now stores this count. The PDP 8 computer has an instruction testing this 12 th bit. 